\title{
PLANTWIDE CONTROL AND DYNAMICS BEHAVIOR OF AN INTEGRATED PLANT COUPLING NITROBENZENE HYDROGENATION AND METHYL-CYCLOHEXANE DEHYDROGENATION
}

\author{
AHTESHAM JAVAID ${ }^{a^{*}}$, COSTIN S. BILDEA ${ }^{a}$
}

\begin{abstract}
Coupling of exothermic and endothermic processes is an application of process intensification where two or more processes can be combined in single unit for better utilization of material and energy. Nitrobenzene hydrogenation and dehydrogenation of Methyl cyclohexane in a single adiabatic reactor was investigated and found efficient, stable and economical in the previous study. The scope of this research is to implement plantwide control structure to analyze the dynamics behavior of an integrated system using Aspen Dynamics. Integrated plants where un-reacted reactants are recycled have high sensitivity towards disturbances. The complexity of the plant is reduced by fixing flow rates of reactants at reactor inlet using feedback control strategy. On introduction of individual and combined disturbances in flow rates of reactants $\pm 10 \%$, the system showed robust behavior and achieved stable operation. The system allows production rate changes keeping high purity of products.
\end{abstract}

Keywords: Aspen Dynamics; Plantwide Control; Process Intensification; Reaction Coupling.

\section{INTRODUCTION}

Process integration is a method of combining several processes in one system. This concept of reducing material and energy consumption by intensification started back in 1970's [1, 2]. The possibility of coupling exothermic and endothermic reactions directly in a single unit is studied by several researchers for improved thermal efficiency, which leads to increase equilibrium conversion and reaction rate [3]. Consequently, simpler reduced size reactor and considerable energy savings can be achieved. Practically these energy savings and cheap reactor investment must outweigh the cost of required

\footnotetext{
a University Politehnica of Bucharest, Department of Chemical and Biochemical Engineering, Str. Polizu 1-7, 011061 Bucharest, Romania

* Corresponding author: ahteshamjavaid@hotmail.com
} 
additional units for separation [4]. Extensive review of integrating exo-endo reactions system, particularly hydrogenation-dehydrogenation is given elsewhere $[5,6]$. Most of the previous work considered stand-alone reactor only, without looking at the economy and controllability of the entire plant. However in some studies coupling behavior of different types of reactions is studied in the entire plant [7-10]. There are number of processes available for coupling but major limitation is the availability of reaction kinetics. This system (methyl-cyclohexane and nitrobenzene) is selected because kinetics parameters are available for both reactions. In our previous study, stand-alone and the integrated processes were compared in a complete plant [11]. Newly proposed coupled process was found economical \& stable in steady state. Non-linear analysis of reactorseparation-recycle shows difficulties in controlling integrated plants when un-reacted reactant is recycled. On introduction of process disturbances, the system becomes highly sensitive and non-linear. This non-linearity could lead to phenomena state multiplicity and closed loop instability [12].

The purpose of this research is to select such a plantwide control structure which could handle non-linear phenomena (snowball effect). Feedback control structure is selected for this study in which reactor is decoupled from plant and production rate can be changed indirectly; either by reactor inlet flow or by reactor condition.

\section{INTEGRATED NITROBENZENE HYDROGENATION - METHYL-CYCLOHEXANE DEHYDROGENATION}

On industrial scale, aniline (AN) is produced by hydrogenation of nitrobenzene (NB). The reaction is highly exothermic and requires large excess of hydrogen in addition of using multi-tubular reactor. On the other hand, toluene (TOL) is produced by dehydrogenation of methyl cyclohexane $(\mathrm{MCH})$, an endothermic process which requires large amount of energy. The reactions are given below.

$$
\begin{array}{ll}
\mathrm{C}_{6} \mathrm{H}_{5}-\mathrm{NO}_{2}+3 \mathrm{H}_{2} \rightarrow \mathrm{C}_{6} \mathrm{H}_{5}-\mathrm{NH}_{2}+2 \mathrm{H}_{2} \mathrm{O} & \Delta \mathrm{H}=-443.0 \mathrm{KJ} / \mathrm{mole} \\
\mathrm{C}_{6} \mathrm{H}_{11}-\mathrm{CH}_{3} \rightarrow \mathrm{C}_{6} \mathrm{H}_{5}-\mathrm{CH}_{3}+3 \mathrm{H}_{2} & \Delta \mathrm{H}=205.3 \mathrm{KJ} / \mathrm{mole}
\end{array}
$$

Figure 1 presents the schematic diagram for combined hydrogenationdehydrogenation process. Reactants ( $\mathrm{MCH}, \mathrm{NB}$ and hydrogen) are fed to single tube adiabatic reactor where both reactions take place. Separation is performed; toluene and aniline are taken as products, water as by-product. Hydrogen and un-reacted $\mathrm{MCH}$ is recycled to be fed with fresh reactants. Physical properties of chemical species are given in Table 1. 


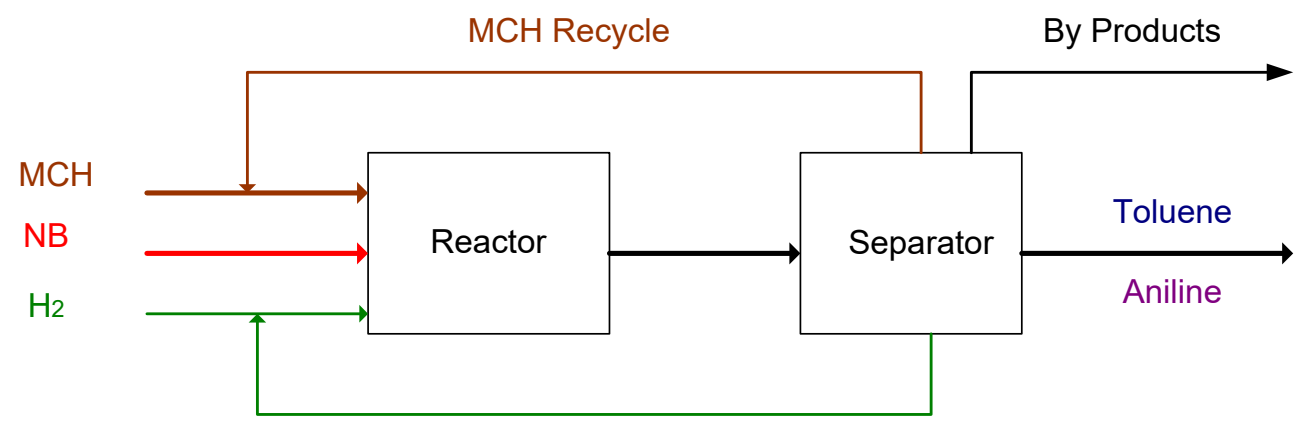

Hydrogen Recycle

Figure 1. Schematic Diagram of MCH Dehydrogenation and NB Hydrogenation

Table 1. Physical Properties of Chemicals [11]

\begin{tabular}{lcccc}
\hline Reactor-outlet species & Boling Point $\left[{ }^{\circ} \mathrm{C}\right]$ & Sol. In Water $[\mathrm{g} / \mathrm{l}]$ & Destination & Separation \\
\hline Hydrogen, $\mathrm{H}_{2}$ & -253 & - & Recycle & \\
Water, $\mathrm{H}_{2} \mathrm{O}$ & 100 & - & By-Product & V-L-L split \\
$\mathrm{AN}, \mathrm{C}_{6} \mathrm{H}_{5} \mathrm{NH}_{2}$ & 184 & 36 & Product & Distillation-1 \\
$\mathrm{NB}, \mathrm{C}_{6} \mathrm{H}_{5} \mathrm{NO}_{2}$ & 211 & 1.9 & Traces & \\
$\mathrm{MCH}, \mathrm{C}_{7} \mathrm{H}_{14}$ & 101 & Insoluble & Product/Recycle & Distillation-2 \\
TOL, $\mathrm{C}_{7} \mathrm{H}_{8}$ & 111 & 0.52 & Product & \\
\hline
\end{tabular}

\section{Design Specification}

Design of an integrated process was achieved using Aspen Plus [13] and dynamic behavior is studied using Aspen Dynamics [14]. The design starts by specifying the reactor performance as reactant conversion. This allows a preliminary mass balance, which gives the reactor-inlet stream. Then, the reactor diameter can be easily calculated. Finding the reactor length which achieves the specified performance requires knowledge of the reaction kinetics. Distillation columns are designed using DSTWU short-cut model which calculates the minimum number of trays $N_{\min }$, and the minimum reflux ratio $R_{\min }$ starting from the recovery of light key \& heavy key components. The number of trays was set $2 N_{\min }$ and the corresponding reflux ratio (R) was calculated, together with the feed tray and the distillate to feed ratio (D/F). These specifications are then used by rigorous distillation model RADFRAC. By means of the "Design Specification" option provided by the simulator, small adjustments of $\mathrm{R}$ and $\mathrm{D} / \mathrm{F}$ are made such that the required distillate and bottoms purities (or recoveries) are achieved. The mixers, vapor-liquid or vapor-liquid-liquid separators 
were designed assuming 10 minutes residence time and 2:1 height to diameter ratio. Specified values of the reactor-inlet flow rates are achieved by changing the plant-inlet flows of fresh reactants.

Peng-Robinson EOS is used in this simulation because it provides more accurate value of state variable calculation $(P, V, T)$ for liquid as well as non-polar gases. The following kinetic expressions were used in the simulation:

Nitrobenzene Hydrogenation (Copper-Nickel Catalyst) [15]:

$$
\begin{aligned}
& r_{1}=k \cdot p_{N B}^{0.5} \cdot p_{H_{2}}^{0.5} \\
& k=0.114 \exp \left(-\frac{8323}{T}\right)
\end{aligned}
$$

$\mathrm{MCH}$ dehydrogenation (Platinum on Alumina Catalyst) [16]:

$$
\begin{array}{ll}
r_{1} & =k_{1} \cdot p_{M C H} \\
k_{1} & =3.07 \times 10^{13} \exp \left(\frac{-26539}{T}\right) \quad \quad \mathrm{kmol} \times \mathrm{m}^{-3} \times \mathrm{s}^{-1} \times \mathrm{Pa}^{-1}
\end{array}
$$

To assess the feasibility of performing the $\mathrm{MCH}$ dehydrogenation and NB hydrogenation simultaneously, an adiabatic reactor was considered. The reactor is fed with $60 \mathrm{kmol} / \mathrm{hr} \mathrm{MCH}, 20 \mathrm{kmol} / \mathrm{hr} \mathrm{NB}$, and $100 \mathrm{kmol} / \mathrm{hr} \mathrm{H}$, at 1.5 bar and $300{ }^{\circ} \mathrm{C}$. The reactants ratio was chosen to approximately match the theoretical value for which the heat of reactions perfectly balances each other. The reacting phase is vapor and all the given values are based on the reactor volume. The length is taken $4 \mathrm{~m}$ and the diameter is $0.5 \mathrm{~m}$ for proper reaction as it is suitable combination of residence time and conversion of $\mathrm{MCH}$ into Toluene. In reactor both catalysts used are mixed in equal proportion. The conversion of nitrobenzene to aniline and $\mathrm{MCH}$ to toluene is $97 \%$ and $76 \%$, respectively. The reactants \& products molar profiles and temperature changes plotted along the reactor length are given in Figure 2. The uniform temperature distribution resists the catalyst deactivation.

(a)

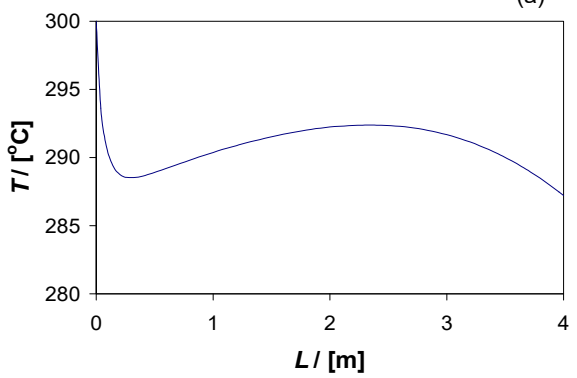

(b)

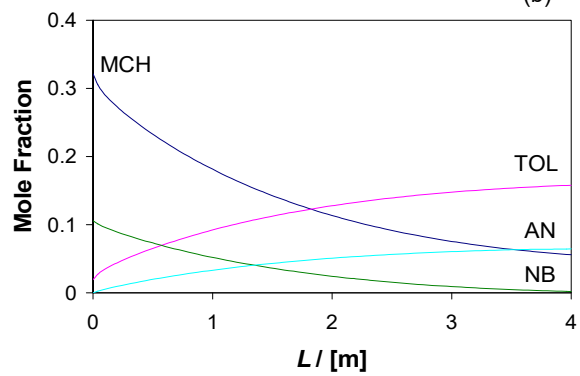

Figure 2. Integrated Reactor: Temperature (a) and Mole Fraction (b) Profiles 


\section{PLANT WIDE CONTROL}

All control systems must perform three basic operations; measurement, decision and action. On the basis of measurement a decision is made, and on the basis of decision an action is taken. The actions taken must response and effect measurement otherwise it is a key mistake in the design, and control will not be achieved [17]. The coupled system in Aspen plus is exported to Aspen Dynamics as flow driven simulation. The core job of plantwide control system is to regulate or control the inventory of products, reactants and impurities. Inventory of reactants within the plant can be controlled in two ways [18]; i) by estimating, directly or indirectly, the inventory of each reactant and then control it by feedback using the corresponding fresh feed as manipulated variable ii) by fixing the fresh feed rate and using the self-regulation property of the mass balances [19].

We used feedback control inventory strategy because of its important advantage of decoupling reactor from the whole plant. The production rate can be changed indirectly, by changing the reactor-inlet flow. Moreover, it can better handle non-linear phenomena (snowball effect [20] or state multiplicity).

Overview of an integrated plant is shown in Figure 3, where fixing the flow rates of methyl-cyclohexane, hydrogen and nitrobenzene at the reactor inlet by manipulating flow rates of fresh feeds. The amount of reactants in the buffer vessels are used as indirect indication of inventories. Therefore, accumulation or depletion of reactants is avoided by adjusting the fresh reactants feed rate. Control structure and stream table of complete plant is given in Figure 4 and Table 2 respectively.

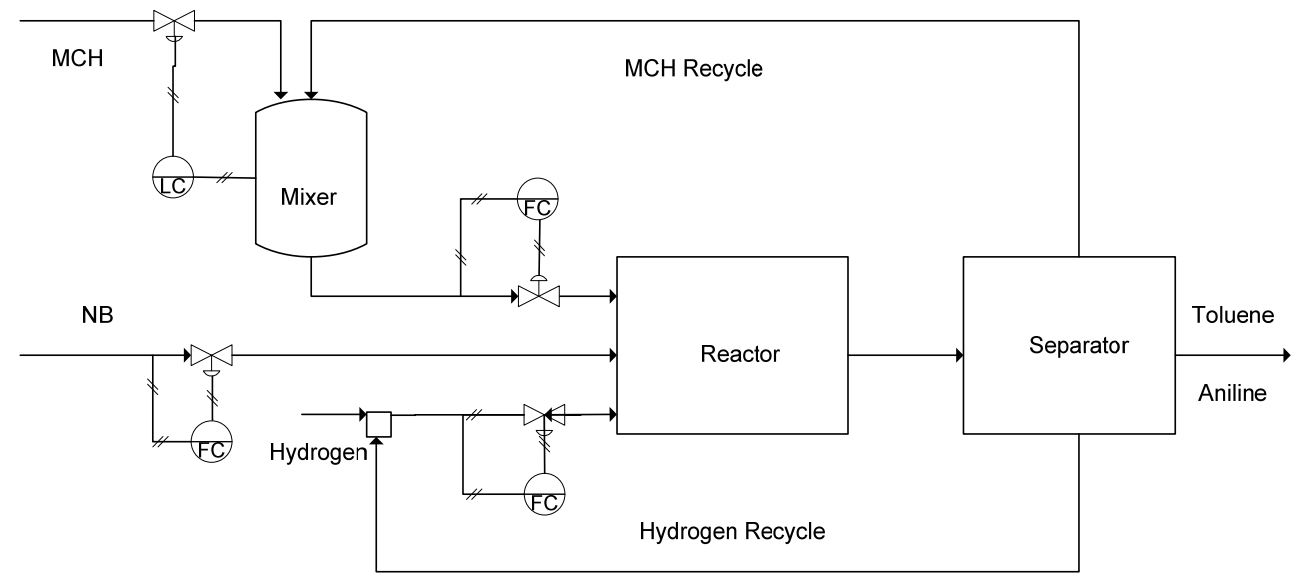

Figure 3. Overview of Control Strategy 


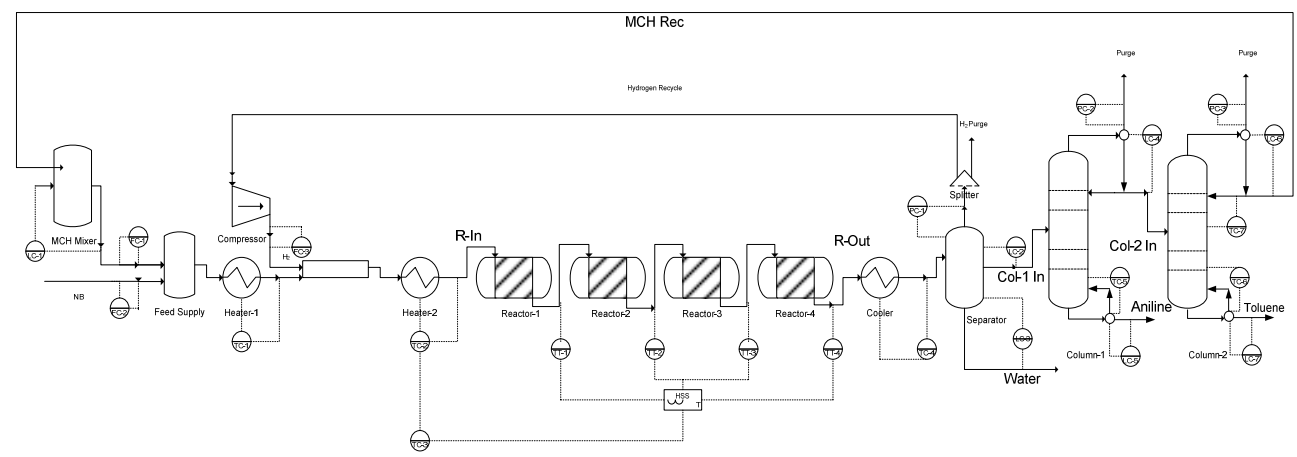

Figure 4. Control Structure of an Integrated Plant

Table 2. Stream Table

\begin{tabular}{lcccccccc}
\hline & R-In & R-Out & \multicolumn{1}{c}{ Col-1 In } & Col-2 In & MCH Rec Aniline Toluene Water \\
\hline Temperature / $\left[{ }^{\circ} \mathrm{C}\right]$ & 300 & 287.2 & 20 & 60 & 50.2 & 183.4 & 88.7 & 20 \\
Pressure / [bar] & 1.5 & 1.5 & 1.2 & 1 & 1.5 & 1 & 0.5 & 1.2 \\
Vapor Fraction & 1 & 1 & 0 & 0 & 0 & 0 & 0 & 0 \\
Mole Flow / [kmol/hr] & 189.2 & 301.82 & 83.86 & 63.95 & 20.56 & 19.9 & 43.17 & 37.43 \\
Mole Fraction & & & & & & & & \\
Methyl-cyclohexane & 0.321 & 0.056 & 0.183 & 0.24 & 0.733 & 0 & 0.005 & 0 \\
Toluene & 0.019 & 0.158 & 0.538 & 0.706 & 0.109 & 0.001 & 0.993 & 0 \\
Hydrogen & 0.528 & 0.576 & 0 & 0 & 0 & 0 & 0 & 0 \\
Nitrobenzene & 0.106 & 0.002 & 0.007 & 0 & 0 & 0.029 & 0 & 0 \\
Aniline & 0 & 0.064 & 0.231 & 0.002 & 0 & 0.97 & 0.002 & 0 \\
Water & 0.025 & 0.145 & 0.04 & 0.053 & 0.157 & 0 & 0 & 1 \\
\hline
\end{tabular}

The control of heater-1, cooler and three phase separator is standard. Heater-1 keeps the temperature of outlet stream at $250{ }^{\circ} \mathrm{C}$. Temperature controller is added to the heater-2 to keep the temperature of stream entering in to the reactor constant at $300{ }^{\circ} \mathrm{C}$. Temperature inside the reactor cannot be measured due to limitation of simulation tool, so to monitor temperature after small length; the reactor of 4 meter length is disintegrated into four reactors of 1 meter length each. Temperature from each reactor output stream is transmitted to high selector switch (HSS). This HSS is attached to the temperature controller and this temperature controller is cascaded to the temperature controller responsible for maintaining temperature of reactor inlet feed. The high selector switch takes the highest temperature of reactor output streams as its output process variable. Pressure drop of 0.001 bar is specified in each reactor. The strategy has an advantage that the disturbances 
in the inlet feed as well as in the reactor are encountered by the temperature controller, so the system will be less effected by the disturbances and returned to its set point quickly. Temperature control structure for reactor is given in Figure 5, and temperature profiles are shown in Figure 6.

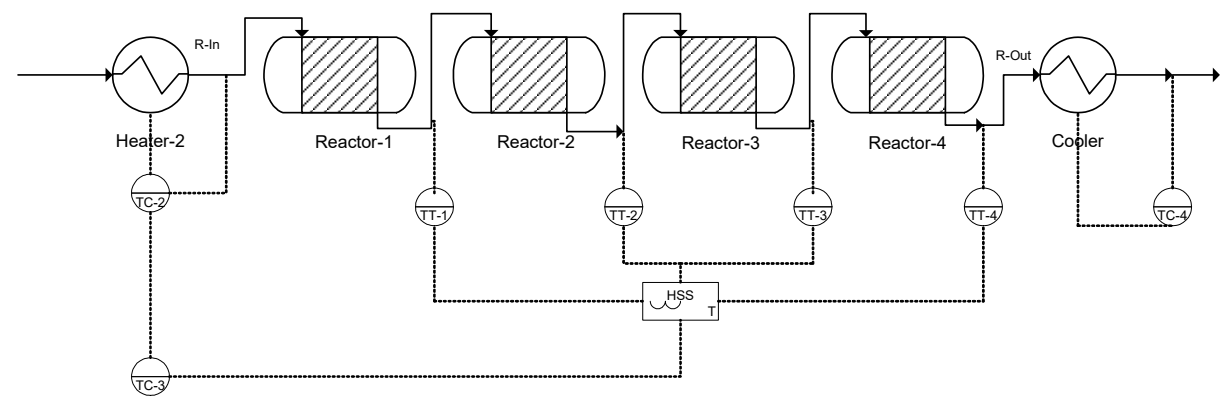

Figure 5. Temperature Control Strategy of Reactor
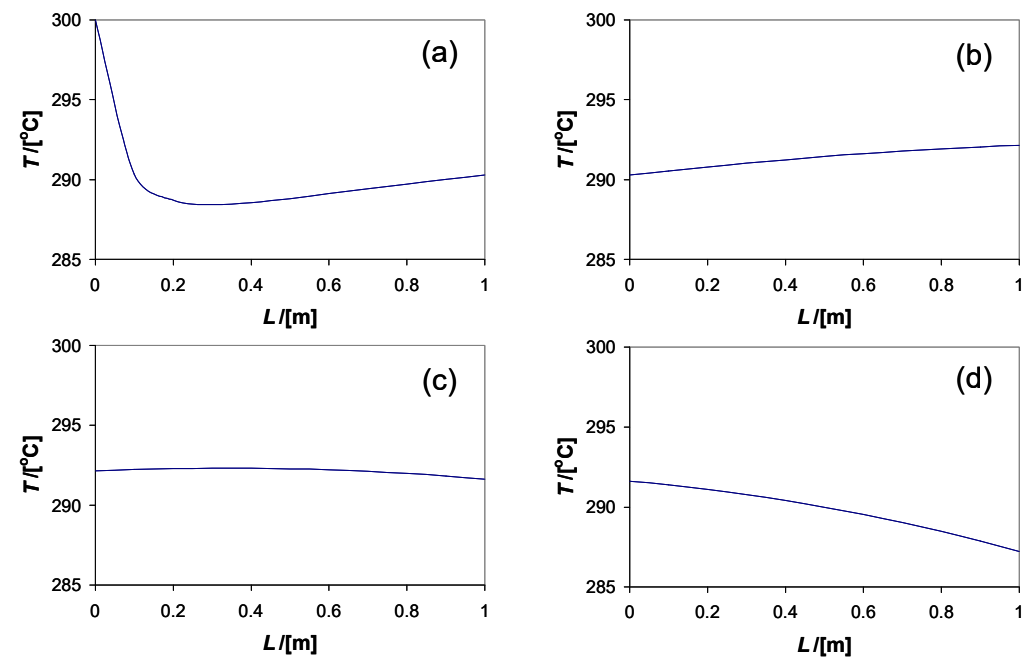

Figure 6. Temperature Profiles of Reactors (a-d)

A temperature controller for measuring stream entering in the separator and maintain its temperature at $20^{\circ} \mathrm{C}$ by manipulating the duty of the condenser. The level controllers in three phase separator control level for water as well as for the stream entering into the column-1, and pressure controller keeps the pressure stable during operation by manipulating condenser duty. In controlling distillation columns; some additional design information regarding 
reflux drum and sump is required by the software. Pressure drop of 0.01 bars is specified along the column and assuming similar geometry of trays throughout the distillation columns. The pressure and condenser drum level are controlled by cooling duty and distillate rate respectively. During dynamic simulation, it is observed that the standard control strategy is not sufficient to control distillation columns. The temperature in the bottom ( $18^{\text {th }}$ tray) of column-1 is controlled by the reboiler duty. It is observed that single temperature controller in column-2 is not sufficient so we use two temperature controllers in top (2nd tray) and in the bottom (36 thay) and are controlled by reflux and reboiler duty respectively. Control strategy and profiles of distillation columns is shown in Figure 7, 8 and 9 respectively, and their detail data is provided in Table 3.

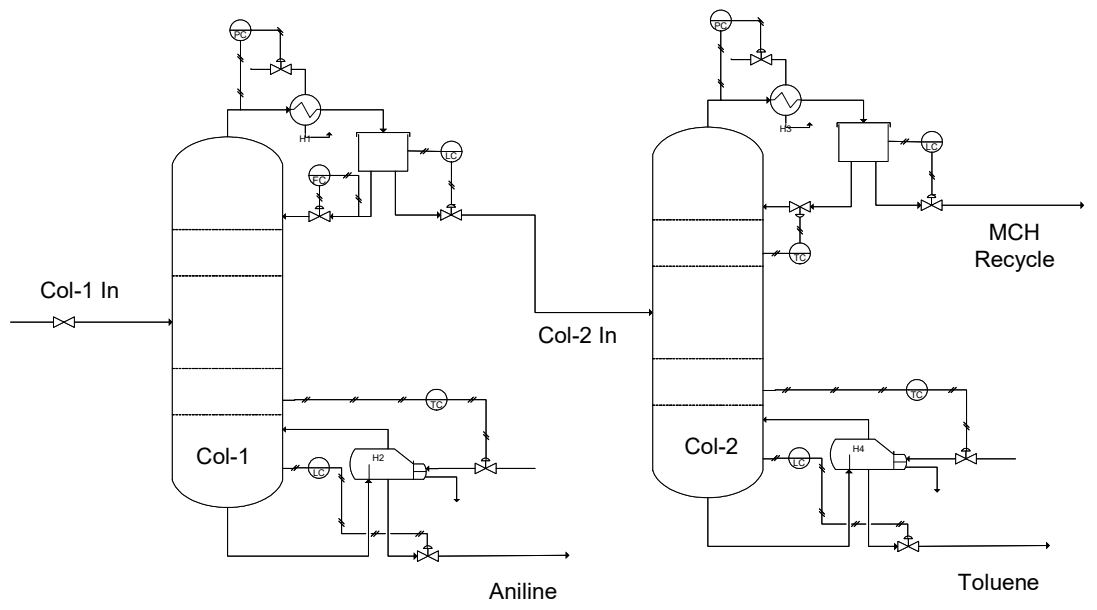

Figure 7. Control Strategy of Distillation Columns
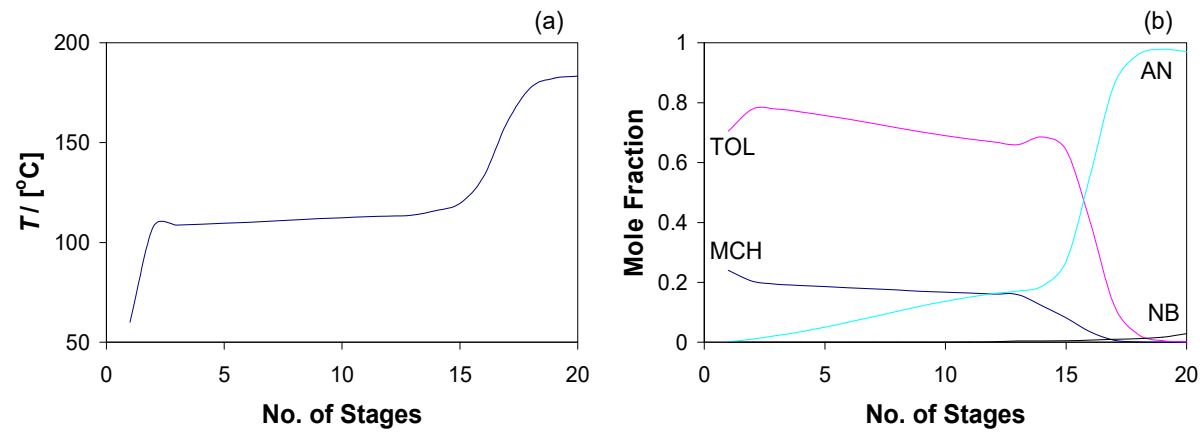

Figure 8. Distillation Column-1: Temperature (a), Mole Fractions (b) Profiles 
(a)

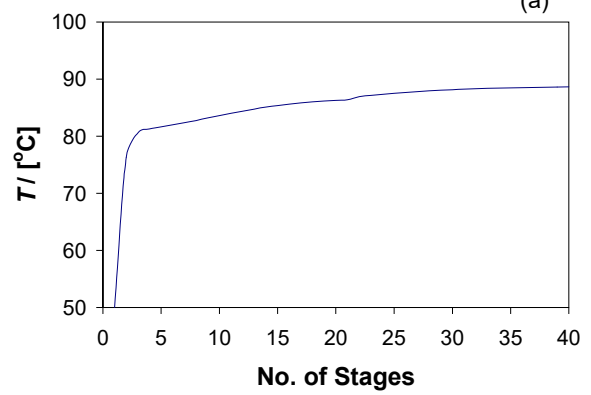

(b)

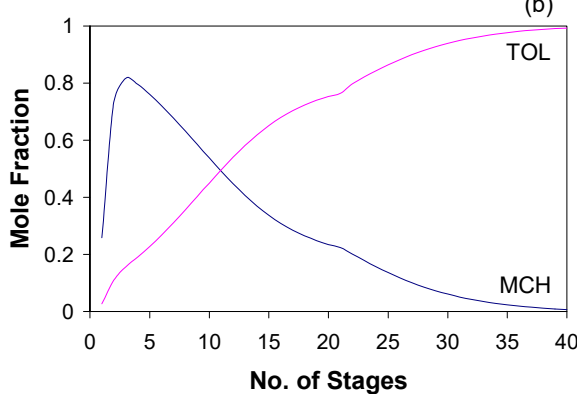

Figure 9. Distillation Column-2: Temperature (a), Mole Fractions (b) Profiles

Table 3. Data of Distillation Column

\begin{tabular}{lcc}
\hline & Column-1 & Column-2 \\
\hline Total Stages & 20 & 40 \\
Feed Stage & 13 & 21 \\
Reflux ratio & 0.204 & 7.178 \\
D/F & 0.7296 & 0.321 \\
Pressure & 1 bar & 0.5 bar \\
Condenser Type & Partial Vapor-liquid & Partial Vapor-liquid \\
& \multicolumn{2}{c}{ Design Specs } \\
Recovery & $99.5 \%(A N)$ & $95 \%(T O L)$ \\
Purity & $97 \%(A N)$ & $99.3 \%(T O L)$ \\
Condenser duty & $-0.853 \mathrm{MW}$ & $-2.93 \mathrm{MW}$ \\
Reboiler duty & $1.125 \mathrm{MW}$ & $2.98 \mathrm{MW}$ \\
\hline
\end{tabular}

The controllers were chosen as PI and were tuned by a simplified version of the direct synthesis method. For each controller, the appropriate range of the controlled and manipulated variables was specified (for example, 30 degrees for temperature measurements, and twice the nominal value for pressure and flow rate manipulations). The controller gain was set to $1 \% / \%$. The integral time was set as equal to the time constant of the process, namely $12 \mathrm{~min}$ for pressure and $20 \mathrm{~min}$ for the temperature control loops. For the level controllers, a large reset time $T_{i}=60 \mathrm{~min}$ was chosen as no tight control was required. Table 4 summarize the stream table and controller settings respectively. The advantage of this control structure is to achieve diverse production rates by changing the flow rates and unique steady state exist for different values of inlet flow rates. 
Table 4. Controller Settings

\begin{tabular}{|c|c|c|c|c|c|c|}
\hline Equipment & $\begin{array}{c}\text { Controlled } \\
\text { Variable, PV }\end{array}$ & $\begin{array}{l}\text { Set Point, } \\
\text { PV }\end{array}$ & $\begin{array}{l}\text { Manipulated } \\
\text { Variable, OP }\end{array}$ & OP range & $\begin{array}{c}\mathrm{Kc} \\
{[\% / \%]}\end{array}$ & $\begin{array}{c}\mathrm{T} \\
{[\mathrm{min}]}\end{array}$ \\
\hline Heater-1 & Tempearture & $250^{\circ} \mathrm{C}$ & Heater duty & $220-280$ & 1 & 20 \\
\hline Heater-2 & Tempearture & $300^{\circ} \mathrm{C}$ & Heater duty & $280-320$ & 1 & 20 \\
\hline Reactor & Tempearture & $300^{\circ} \mathrm{C}$ & Heater duty & $285-315$ & 1 & 20 \\
\hline \multirow[t]{3}{*}{ Separator } & Pressure & 1.2 bar & Condenser duty & $0-2.4$ & 20 & 12 \\
\hline & Level Liq-1 & $1.25 \mathrm{~m}$ & Col-1 in flow & $0-2.5$ & 10 & 60 \\
\hline & Level Liq-2 & $0.165 \mathrm{~m}$ & Water out flow & $0-0.33$ & 10 & 60 \\
\hline Cooler & Tempearture & $20^{\circ} \mathrm{C}$ & Condenser duty & $10-30$ & 1 & 20 \\
\hline \multirow[t]{4}{*}{ Column-1 } & Pressure & 1 bar & Condenser duty & $0-2$ & 20 & 12 \\
\hline & $\begin{array}{c}\text { Level } \\
\text { Reflux Drum }\end{array}$ & $1.1875 \mathrm{~m}$ & Flow top-1 & $0-2.375$ & 10 & 60 \\
\hline & $\begin{array}{l}\text { Level } \\
\text { Sump }\end{array}$ & $1.375 \mathrm{~m}$ & Aniline flow & $0-2.75$ & 10 & 60 \\
\hline & $\begin{array}{c}\text { Temperature } \\
\text { Bottom }\end{array}$ & $145^{\circ} \mathrm{C}$ & Reboiler duty & $120-170$ & 1 & 20 \\
\hline \multirow[t]{5}{*}{ Column-2 } & Pressure & 0.5 bar & Condenser duty & $0-1$ & 20 & 12 \\
\hline & $\begin{array}{c}\text { Level } \\
\text { Reflux Drum }\end{array}$ & $1.875 \mathrm{~m}$ & $\mathrm{MCH}$ recycle flow & $0-3.75$ & 10 & 60 \\
\hline & $\begin{array}{l}\text { Level } \\
\text { Sump }\end{array}$ & $2 \mathrm{~m}$ & Toluene flow & $0-4$ & 10 & 60 \\
\hline & $\begin{array}{c}\text { Temperature } \\
\text { Top }\end{array}$ & $76^{\circ} \mathrm{C}$ & Reflux rate & $50-100$ & 1 & 20 \\
\hline & $\begin{array}{c}\text { Tempearture } \\
\text { Bottom }\end{array}$ & $105^{\circ} \mathrm{C}$ & Reboiler duty & $80-120$ & 1 & 20 \\
\hline
\end{tabular}

\section{PLANT DYNAMICS}

Performance of process control system can be analyzed conveniently through dynamic simulation. In order to prove the stability of the operating point and the resiliency with respect to disturbances, plant dynamics must be considered. A dynamic model of the plant is built in Aspen Dynamics, and the flexibility in manipulating the inlet flow rates is investigated. Change in flow rates of streams entering into the system is very crucial parameter. As discussed earlier that by changing flow rates, non-linearity occurs in system, so to check the reliability of the integrated system, this variable is chosen. The effect of manipulation in inlet flows are plotted to observe the behavior on product purity, production and recycle rates.

In Figure 10, starting from the steady state, the reactor inlet feed of $\mathrm{MCH}$ is increased $10 \%$ at $t=1 \mathrm{hr}$ and continued simulation for $5 \mathrm{hrs}$. Similarly in next simulation $\mathrm{MCH}$ feed is decreased $10 \%$. The change of the $\mathrm{MCH}$ feed 
PLANTWIDE CONTROL AND DYNAMICS BEHAVIOR OF AN INTEGRATED PLANT COUPLING NITROBENZENE HYDROGENATION AND METHYL-CYCLOHEXANE DEHYDROGENATION
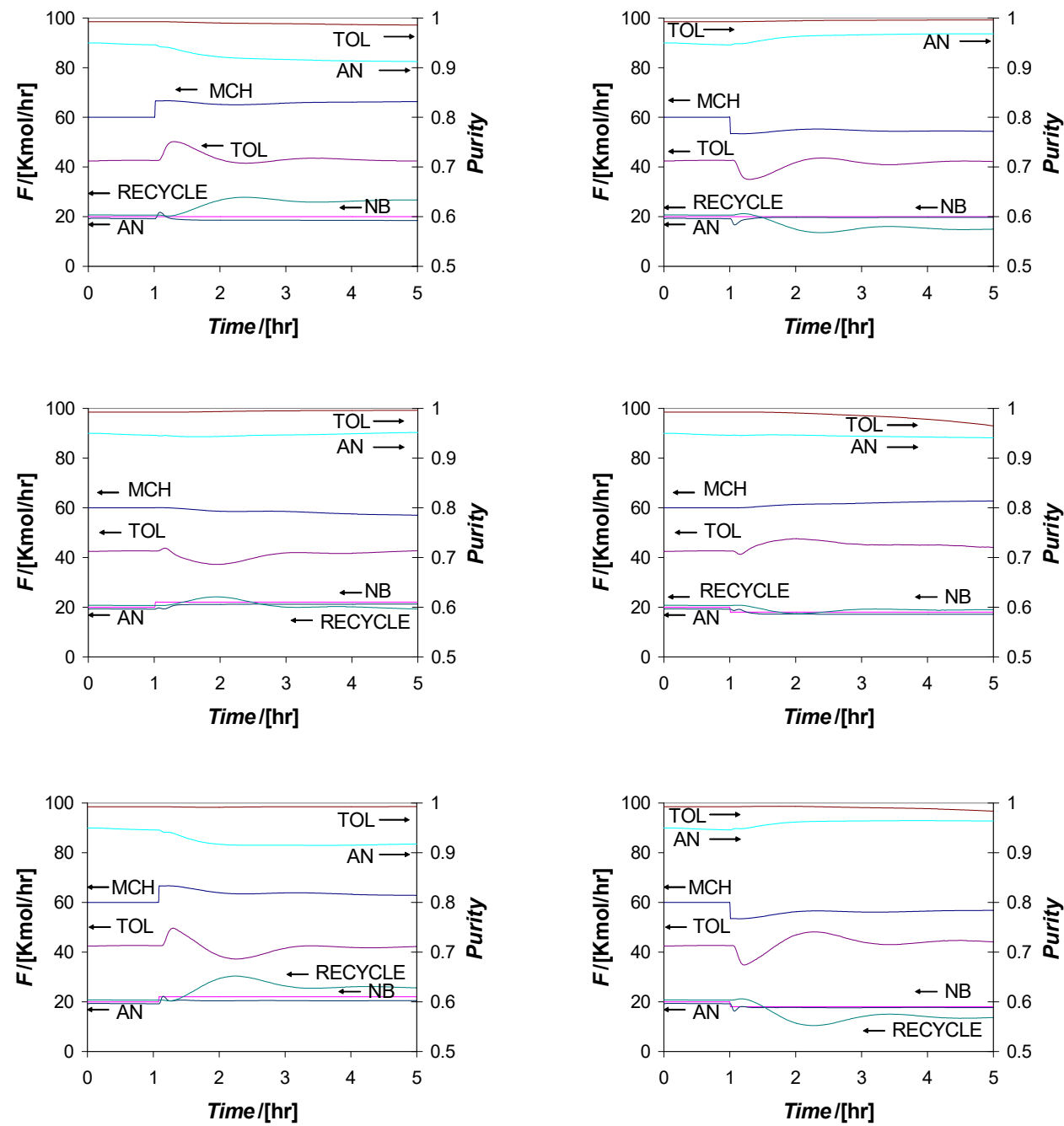

Figure 10. Effect of $\mathrm{MCH}$ and NB (10\% Increase Left, $10 \%$ Decrease Right)

rate effect production of toluene, recycle of $\mathrm{MCH}$ and purity of aniline but aniline production and toluene purity is less effected. On the same lines, changed the NB feed rate by increasing and decreasing $10 \%$, which effected toluene production rate, $\mathrm{MCH}$ recycle and aniline purity. Aniline production and purity of toluene is again less effected by the disturbances. In third simulation, inlet flow rates of both $\mathrm{MCH}$ and $\mathrm{NB}$ together are changed. This change introduced in the system effect toluene production rate, $\mathrm{MCH}$ recycle and aniline purity. 
After investigating integrated system with changes (increase and decrease) in inlet flows through separate simulations, the robustness of system is checked by multiple flow disturbances in single simulation. In Fig. 11, the inlet flows of $\mathrm{MCH}$ and $\mathrm{NB}$ (independently and combined) varied for $10 \mathrm{hr}$ simulation time. They are increased $10 \%$ at $t=1 \mathrm{hr}$ and decreased at $t=5 \mathrm{hr}$. The obtained results are similar and comparable to results achieved in separate simulations. The integrated plant can withstand independent disturbances as well as on combined disturbances. It has been observed that the normal operating point is stable, and if the system is disturbed, it reaches new steady state.
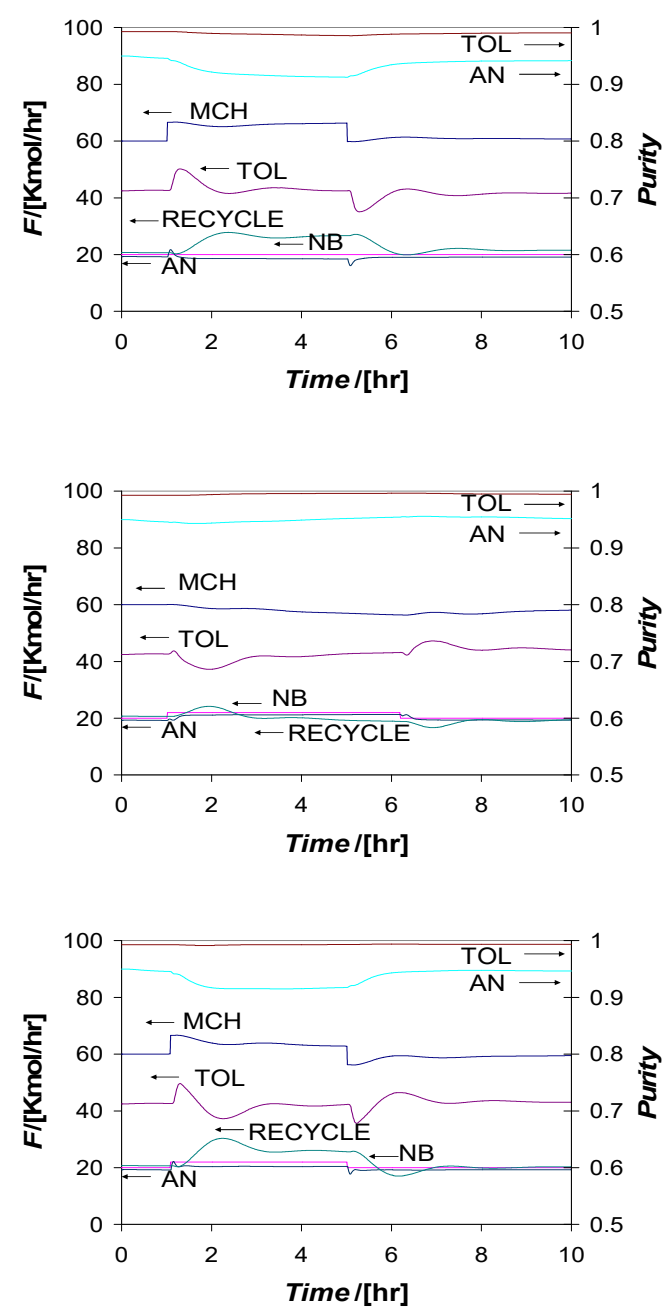

Figure 11. Effect of $\mathrm{MCH}$ and $\mathrm{NB}( \pm 10 \%)$ 
PLANTWIDE CONTROL AND DYNAMICS BEHAVIOR OF AN INTEGRATED PLANT COUPLING NITROBENZENE HYDROGENATION AND METHYL-CYCLOHEXANE DEHYDROGENATION

\section{CONCLUSIONS}

On the basis of results achieved in previous study, a plant wide control structure is implemented on the coupled system and stable operation of plant is observed. The complexity of the plant is reduced by fixing the inlet flow of methyl-cyclohexane, nitrobenzene and hydrogen at reactor inlet. The feed rate of $\mathrm{NB}$ and $\mathrm{MCH}$ is changed (increased and decreased), independently \& combined and effect on recycle stream, production rates of products (Toluene and Aniline) and on their purity is observed. The system showed a robust behavior, resiliency with respect to input disturbances $( \pm 10 \%)$, allowing for production rate changes and maintaining high purity of products. The result achieved in this study is also applicable to processes of practical relevance.

\section{REFERENCES}

1. F. Friedler, Appl. Therm. Eng., 2010, 30, 2270-2280.

2. R. Smith, Appl. Therm. Eng., 2000, 20 (15-16), 1337-1345.

3. G. Towler, S. Lynn, Chem. Eng. Sci., 1994, 49 (16), 2585-2591.

4. P. R. Pujado, M. Moser, Catalytic Reforming, In Handbook of Petroleum Processing, D. S. J. S. Jones, P. R. Pujado, Eds., Springer, Dordrecht, 2008, Chapter 5, pp. 217-237.

5. M. R Rahimpour, M. R. Dehnavi, F. Allahgholipour, D. Iranshahi, S. M. Jokar, Appl. Energy, 2012, 99, 496-512.

6. C. V Pramod, C. Raghavendra, K. Hari Prasad Reddy, G. V Ramesh Babu, K. S. Rama Rao, B. David Raju, J. Chem. Sci., 2014, 126(2), 311-317.

7. P. Octavian, V. van der Last, C. S. Bildea, P. Altimari, Chem. Prod. Process Model., 2009, 4 (5), Article 19, 1-21.

8. A. Javaid, C. S. Bildea, Chem. Eng. Technol., 2014, 37 (9), 1515-1524.

9. A. Javaid, C. S. Bildea, Period. Polyteh. Chem. Eng., 2014, 58 (2), 165-169.

10. A. Javaid, C. S. Bildea, U.P.B. Sci. Bull., Series B, 2014, 76 (3), 33-42.

11. A. Javaid, C. S. Bildea, Asia-Pac. J. Chem. Eng., 2018, 13 (4), 1-12.

12. M. Horvath, A. Szitkai, P. Mizsey, Period. Polyteh. Chem. Eng., 2007, 51(2), 37-44.

13. ASPENTECH, Aspen Plus Getting Started Building and Running a Process Model, ASPEN Technology, Burlington, 2010.

14. ASPENTECH, Aspen Dynamics User Guide, ASPEN Technology, Burlington, 2009.

15. D. N. Rihani, T. K. Naraynan, L. K. Doraiswamy, Ind. Eng. Chem. Process Des. Dev., 1965, 4(4), 403-410.

16. G. Maria, A. Marin, C. Wyss, S. Muller, E. Newson, Chem. Eng. Sci., 1996, 51(11), 2891-2896. 
17. C. Smith, A. Corripio, Principles and Practice of Automatic Process Control, $3^{\text {rd }}$ ed., John Willey \& Sons, USA, 2006, pp. 415-425.

18. C. S. Bildea, A. C. Dimian, Ind. Eng. Chem. Res., 2003, 42(20), 4578-4585.

19. J. J. Downs, Distillation Control in a Plantwide Control Environment in Practical Distillation Control, W. L. Luyben, Eds., Springer, New York, NY, 1992, Chapter 20, pp. 413-439.

20. W. L. Luyben, Ind. Eng. Chem. Res., 1994, 33(2), 299-305. 